\title{
Nicotinoprotein (NADH-containing) alcohol dehydrogenase from Rhodococcus erythropolis DSM 1069: an efficient catalyst for coenzyme- independent oxidation of a broad spectrum of alcohols and the interconversion of alcohols and aldehydes
}

\author{
Peter Schenkels and Johannis A. Duine
}

Author for correspondence: Johannis A. Duine. Tel: +31 15 2785051. Fax: +31 152782355. e-mail: j.a.duine@stm.tudelft.nl

Department of

Microbiology and

Enzymology, Delft

University of Technology,

Julianalaan 67, NL-2628 BC

Delft, The Netherlands

\begin{abstract}
Extracts from benzyl-alcohol-grown Rhodococcus erythropolis DSM 1069 showed NAD(P)-independent, $\mathbf{N}, \mathbf{N}$-dimethyl-4-nitrosoaniline (NDMA)dependent alcohol dehydrogenase activity. The enzyme exhibiting this activity was purified to homogeneity and characterized. It appears to be a typical nicotinoprotein as it contains tightly bound NADH acting as cofactor instead of coenzyme. Other characteristics indicate that it is highly similar to the known nicotinoprotein alcohol dehydrogenase (np-ADH) from Amycolatopsis methanolica : it is a homotetramer of $150 \mathrm{kDa}$; N-terminal amino acid sequencing ( 22 residues) showed that $77 \%$ of these amino acids are identical in the two enzymes; it has optimal activity at pH 7.0; it lacks NAD(P)Hdependent aldehyde reductase activity; it catalyses the oxidation of a broad range of (preferably) primary and secondary alcohols, either aliphatic or aromatic, and formaldehyde, with the concomitant reduction of the artificial electron acceptor NDMA. NDMA could be replaced by an aldehyde, but not formaldehyde, the substrate specificity of the enzyme for the aldehydes reflecting that for the corresponding alcohols. The latter also applied to the low aldehyde dismutase activity displayed by the enzyme. From this, together with the results of the induction studies, it is concluded that np-ADH functions as the main alcohol-oxidizing enzyme in the dissimilation of many, but not all, alcohols by $R$. erythropolis and may also catalyse coenzyme-independent interconversion of alcohols and aldehydes under certain circumstances. It is anticipated that the enzyme may be of even wider significance since structural data indicate that np-ADH is also present in other (nocardioform) actinomycetes.
\end{abstract}

Keywords : nicotinoprotein alcohol dehydrogenase, Rhodococcus erythropolis

\section{INTRODUCTION}

The Gram-positive bacterial genus Rhodococcus, belonging to the nocardioform actinomycetes, is known

Abbreviations: MNO, methanol:NDMA oxidoreductase; NDMA, $N, N-$ dimethyl-4-nitrosoaniline; $\mathrm{np}-\mathrm{ADH}$, nicotinoprotein alcohol dehydrogenase.

The EMBL accession number for the sequence reported in this paper is P81747. for its ability to metabolize a great variety of natural compounds as well as xenobiotics (Finnerty, 1992; Warhurst \& Fewson, 1994; Bell et al., 1998). Often, one of the steps in the degradation pathway of such compounds is the oxidation of an alcohol into the corresponding aldehyde or ketone. Several alcohol dehydrogenases have been (partly) characterized from species belonging to this genus, e.g. NAD-dependent coniferyl alcohol dehydrogenase (Jaeger et al., 1981; Jaeger, 1988), NAD/mycothiol-dependent for- 
maldehyde dehydrogenase (Eggeling \& Sahm, 1984, 1985; van Ophem et al., 1992; van Ophem \& Duine, 1994; Misset-Smits et al., 1997) and methanol:N,Ndimethyl-4-nitrosoaniline (NDMA) oxidoreductase (MNO) from R. erythropolis DSM 1069 (van Ophem et al., 1993); MNO from R. rhodochrous LMD 89.129 (van Ophem et al., 1993) and from Rhodococcus sp. NI86/21 (Nagy et al., 1995), which has since been identified as R. erythropolis (de Schrijver et al., 1997); NAD-dependent propan-2-ol dehydrogenase from $R$. rhodochrous PNKb1 (Ashraf \& Murrell, 1990, 1992); NADH-dependent carbonyl reductase from R. erythropolis DSM 743 (Peters et al., 1992, 1993; Zelinski et al., 1994); NAD-dependent long-chain secondary alcohol dehydrogenase from R. erythropolis ATCC 4277 (Ludwig et al., 1995); NAD-dependent secondary alcohol dehydrogenase from Rhodococcus sp. GK1 (Krier et al., 1998). Although not clear for every case, it appears from this that the functional role of these enzymes is confined to the oxidation of one particular alcohol and that an alcohol dehydrogenase with a broad induction and substrate specificity pattern and kinetic parameter values compatible with a broad physiological role in dissimilatory alcohol oxidation has not been found so far in rhodococci.

MNO (EC 1.1.99.-) is a member of the group of nicotinoprotein alcohol dehydrogenases, i.e. enzymes which contain tightly bound, non-exchangeable $\mathrm{NAD}(\mathrm{P})(\mathrm{H})$ in the active site acting as cofactor instead of coenzyme. MNO was detected in Amycolatopsis methanolica NCIB 11946 (grown on methanol, ethanol, butan-1-ol, hexan-1-ol or acetate) and Mycobacterium gastri MB 19 (grown on methanol, propan-1-ol, propan2-ol or glycerol) (Bystrykh et al., 1993a, b; van Ophem et al., 1993), i.e. Gram-positive, methylotrophic actinomycetes closely related to (non-methylotrophic) rhodococci. It is a $490-500 \mathrm{kDa}$ homodecameric class III alcohol dehydrogenase, each subunit containing a tightly, but not covalently bound $\operatorname{NADP}(\mathrm{H})$ cofactor (Bystrykh et al., 1993a). Since no transfer of reducing equivalents takes place to externally added $\operatorname{NAD}(\mathrm{P})$, $\mathrm{MNO}$ is not active in the common assays for NAD $(\mathrm{P})$ dependent alcohol dehydrogenases. Its alcohol dehydrogenase activity can be demonstrated, however, by using the artificial electron acceptor NDMA. In such an assay, the enzyme acts as a coenzyme-independent alcohol: NDMA oxidoreductase and obeys a ping-pong mechanism. Moreover, MNO catalyses the dismutation of formaldehyde and the NADH-dependent reduction of aldehydes (Bystrykh et al., 1993b). Gene-disruption mutants of A. methanolica lacking a functionally active gene encoding MNO were unable to grow on methanol, ethanol, propan-1-ol or butan-1-ol as sole carbon source (Hektor \& Dijkhuizen, 1996; Hektor, 1997). It seems, therefore, that MNO is crucial for oxidation of these $\mathrm{C}_{1}-\mathrm{C}_{4}$ alcohols.

Surprisingly, apart from MNO, A. methanolica (grown on methanol, ethanol, butan-1-ol, hexan-1-ol or acetate) contains a second nicotinoprotein alcohol: NDMA oxidoreductase (EC 1.1.99.-) (van Ophem et al., 1993) for which the name nicotinoprotein alcohol dehydrogenase (np-ADH) has been proposed (Piersma et al., 1998). The enzyme is quite different from $\mathrm{MNO}$ with respect to protein structure and catalytic performance. np-ADH is a homotri- or tetrameric class I alcohol dehydrogenase of $120 \mathrm{kDa}$, each $39 \mathrm{kDa}$ subunit containing firmly, noncovalently bound $\mathrm{NADH}$ as cofactor. It catalyses the $\mathrm{NAD}(\mathrm{P})$-independent oxidation of various primary alcohols (but not methanol) with the concomitant reduction of NDMA, according to a ping-pong mechanism. However, in contrast to MNO it catalyses neither the dismutation of formaldehyde nor the NADHdependent reduction of aldehydes. Despite the fact that $\mathrm{MNO}$ and np-ADH are simultaneously induced during growth on certain alcohols (methanol, ethanol, butan1-ol or hexan-1-ol), and ethanol, propan-1-ol and butan1-ol are good substrates for both enzymes in vitro, the physiological role of MNO in A. methanolica cannot be taken over by np-ADH, as judged from the inability of mutants lacking the MNO-encoding gene to grow on these alcohols. Since such studies using mutants lacking a functionally active gene encoding np-ADH have not been performed so far, the physiological role of np-ADH remains to be elucidated.

During our earlier work on novel types of alcohol dehydrogenases involved in the kinetic resolution of racemic alcohols (Geerlof et al., 1994), strong indications were obtained that a nicotinoprotein alcohol dehydrogenase found in certain rhodococci is involved in resolving enantiomeric mixtures of alcohols. To study this in more detail, R. erythropolis DSM 1069 was chosen as a model organism. From these studies it appeared that this strain is able to produce $\mathrm{MNO}$ (characterization to be published elsewhere) as well as np-ADH. Here we report on the induction, purification and characterization of np-ADH.

\section{METHODS}

Chemicals. Yeast extract and bactopeptone were obtained from Difco. NAD $(\mathrm{P})$ and $\mathrm{NAD}(\mathrm{P}) \mathrm{H}$ were from Boehringer Mannheim. All other chemicals used in this study were of the highest quality available from Sigma-Aldrich.

Cultivation and induction experiments. Rhodococcus erythropolis DSM 1069 was precultivated on a medium containing $2 \%(\mathrm{w} / \mathrm{v})$ D-glucose, $1 \%(\mathrm{w} / \mathrm{v})$ bactopeptone, $0.5 \%(\mathrm{w} / \mathrm{v})$ $\mathrm{NaCl}$ and $0.05 \%(\mathrm{w} / \mathrm{v})$ yeast extract in a rotary shaker incubator (200 r.p.m.) for $48 \mathrm{~h}$ at $30^{\circ} \mathrm{C}$. For induction studies, $25 \mathrm{ml}$ precultures were used to inoculate 21 Erlenmeyer flasks, containing 0.51 mineral salt medium (Eggeling \& Sahm, 1984), $0.05 \%(\mathrm{w} / \mathrm{v})$ yeast extract, and growth substrate (see legend of Table 1). The flasks were shaken (at 200 r.p.m., at $30^{\circ} \mathrm{C}$ ) and the cells were harvested in the late exponential growth phase (after approximately $48 \mathrm{~h}$, except for growth on citronellol, which required $168 \mathrm{~h}$ ) by centrifugation $(20 \mathrm{~min}$ at $16300 \mathrm{~g}$, at $4^{\circ} \mathrm{C}$ ) and washed twice with $10 \mathrm{mM}$ potassium phosphate buffer, $\mathrm{pH} 7 \cdot 0$, at $4^{\circ} \mathrm{C}$. An aliquot of cell paste (typically 1-2 g) was resuspended in an equal volume of the same buffer, sonicated (using an MSE sonicator for $4 \times 10 \mathrm{~s}$ on ice, at high power, amplitude $2,10 \mu \mathrm{m}$ peak to peak), and centrifuged ( $30 \mathrm{~min}$ at $20000 \mathrm{~g}$, at $4^{\circ} \mathrm{C}$ ). The supernatant was 
used as the cell-free extract and assayed for various alcohol dehydrogenase activities.

To produce cells as starting material for isolation of np-ADH, growth was carried out in a fermenter (model Bio Bench 20, Applikon Dependable Instruments) containing 161 mineral salt medium (Eggeling \& Sahm, 1984) with benzyl alcohol as growth substrate (added to the cell suspension in three portions resulting in a concentration of $10 \mathrm{mM}$ at time 0,24 and $48 \mathrm{~h}$ ). The culture was stirred at 400 r.p.m. and aerated at $51 \mathrm{~min}^{-1}$. During growth, the $\mathrm{pH}$ was controlled at $7 \cdot 0 \pm 0 \cdot 2$ by automatic titration with $4 \mathrm{M} \mathrm{NaOH}$ and $2 \mathrm{M} \mathrm{H}_{2} \mathrm{SO}_{4}$. After $72 \mathrm{~h}$ of growth, the cell suspension was concentrated to approximately $1.5 \mathrm{l}$ by ultrafiltration. The cells were harvested by centrifugation $\left(20 \mathrm{~min}\right.$ at $16300 \mathrm{~g}$, at $\left.4{ }^{\circ} \mathrm{C}\right)$, washed with $10 \mathrm{mM}$ potassium phosphate buffer, $\mathrm{pH} 7 \cdot 0$, and stored frozen at $-40{ }^{\circ} \mathrm{C}$.

Enzyme purification. All purification steps were performed at room temperature unless indicated otherwise. The fractions were assayed for the presence of np-ADH, MNO or NAD $(\mathrm{P})$ dependent benzyl alcohol dehydrogenase activities. Thawed cell paste $(50 \mathrm{~g})$ was resuspended in an equal volume of $10 \mathrm{mM}$ potassium phosphate buffer, $\mathrm{pH} 7 \cdot 0$, at $4{ }^{\circ} \mathrm{C}$. After adding bovine DNase I, the suspension was passed three times through a French pressure cell under a pressure of $27.6 \mathrm{MPa}$. Centrifugation $\left(60 \mathrm{~min}\right.$ at $16300 \mathrm{~g}$, at $\left.4^{\circ} \mathrm{C}\right)$ yielded the cellfree extract. The extract was dialysed for $1 \mathrm{~h}$ against $1 \mathrm{M}$ potassium phosphate buffer, $\mathrm{pH} 7 \cdot 0$, at $4{ }^{\circ} \mathrm{C}$, and centrifuged $\left(20 \mathrm{~min}\right.$ at $16300 \mathrm{~g}$, at $\left.4{ }^{\circ} \mathrm{C}\right)$. Aliquots $(10 \mathrm{ml})$ of the supernatant were applied to a $40 \mathrm{ml}$ Phenyl-Sepharose FF hydrophobic interaction column (Pharmacia Biotech) equilibrated with $1 \mathrm{M}$ potassium phosphate buffer, $\mathrm{pH} 7 \cdot 0$, at $4{ }^{\circ} \mathrm{C}$. A linear gradient of potassium phosphate $(1 \mathrm{M}-10 \mathrm{mM}, \mathrm{pH} 7 \cdot 0)$

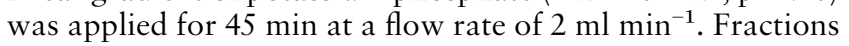
showing np-ADH activity (eluting in the final part of the gradient) were concentrated by centrifugation $(3000 \mathrm{~g})$ using a $30 \mathrm{kDa}$ cutoff filter (Centriprep 30, Amicon). Concentrate obtained from five separate runs on Phenyl-Sepharose was applied to a Poros HQ $(1 \times 10 \mathrm{~cm})$ anion-exchange column (Boehringer Mannheim) equilibrated with $20 \mathrm{mM}$ potassium phosphate buffer, $\mathrm{pH} 7 \cdot 2$. A linear gradient of potassium chloride $(0-1.5 \mathrm{M})$ in the same buffer was applied for $60 \mathrm{~min}$ at a flow rate of $2 \mathrm{ml} \mathrm{min}{ }^{-1}$. The np-ADH activity, eluting at $35 \mathrm{mM} \mathrm{KCl}$, was concentrated as above and applied in $200 \mu \mathrm{l}$ portions to a Superdex $200(1 \times 30 \mathrm{~cm})$ gel-filtration column (Pharmacia) equilibrated with $10 \mathrm{mM}$ potassium phosphate buffer, $\mathrm{pH} 7 \cdot 0$, containing $0.2 \mathrm{M} \mathrm{KCl}$, at a flow rate of $0.5 \mathrm{ml}$ $\mathrm{min}^{-1}$. Fractions with np-ADH activity from 10 separate runs were pooled and stored frozen at $-80^{\circ} \mathrm{C}$.

Enzyme assays. All measurements were performed in duplicate at $20^{\circ} \mathrm{C}$. np-ADH activity was measured by following the reduction rate of NDMA at $440 \mathrm{~nm}$ with benzyl alcohol as electron donor. The reaction mixture contained (total volume $1 \mathrm{ml}$ ) : benzyl alcohol, $20 \mu \mathrm{M}$; NDMA, $28 \mu \mathrm{M}$; potassium phosphate buffer, $\mathrm{pH} 7 \cdot 0,10 \mathrm{mM}$. The reaction was started by the addition of an appropriate amount of enzyme. Specific activities were calculated using a molar absorption coefficient for NDMA of $35400 \mathrm{M}^{-1} \mathrm{~cm}^{-1}$ at $440 \mathrm{~nm}$ (Dunn \& Bernard, 1971). In order to determine whether extracts exhibited NDMA-dependent alcohol oxidation activity for the alcohol used as growth substrate, benzyl alcohol in the assay was replaced by this alcohol. The optimal concentration of the latter (as indicated by the values in parentheses in Table 1), yielding an apparent maximal rate, was determined by varying each substrate in the range from $5 \mu \mathrm{M}$ to $25 \mathrm{mM}$ (or up to saturation in the case of alcohols with low solubility). MNO activity was measured in $50 \mathrm{mM}$ potassium phosphate buffer, $\mathrm{pH} 6 \cdot 3$, by following the reduction of NDMA $(28 \mu \mathrm{M}$, final concentration), starting the reaction by the addition of methanol (25 mM, final concentration) (Bystrykh et al., 1993b). NAD(P)-dependent alcohol dehydrogenase activities were determined in $0 \cdot 1 \mathrm{M}$ sodium pyrophosphate buffer, $\mathrm{pH}$ 9.0 (Duine et al., 1984) by measuring the formation rate of $\mathrm{NAD}(\mathrm{P}) \mathrm{H}$ at $340 \mathrm{~nm}$ in the presence of the alcohol used as growth substrate (apparent maximal rates were determined as indicated above). Assays for aldehyde dismutase activity were carried out in a $1.5 \mathrm{ml}$ reaction vessel containing (final concentrations) $50 \mathrm{mM}$ potassium phosphate buffer, $\mathrm{pH} 7 \cdot 0$, aldehyde (formaldehyde, $5 \mathrm{mM}$; acetaldehyde, $2 \mathrm{mM}$; propionaldehyde, $0.1 \mathrm{mM}$; methylglyoxal, $5 \mathrm{mM}$; benzaldehyde, $5 \mathrm{mM}$; phenylacetaldehyde, $0.2 \mathrm{mM}$ ) and an appropriate amount of enzyme (typically $0.67 \mu \mathrm{M}$ ) in a total volume of $1.0 \mathrm{ml}$. The reaction was started by the addition of enzyme. Samples $(100 \mu \mathrm{l})$ were taken at regular intervals and the reaction was stopped by the addition of $2 \mu \mathrm{l}$ formic acid $(100 \%)$ [in the case of formaldehyde, aqueous acetic acid $(10 \%)$ was used instead]. After centrifugation (2 min at $20000 \mathrm{~g}$ ), the remaining substrate and the products were determined by injecting $1.0 \mu \mathrm{l}$ of supernatant into the HPInnowax GC-column (see below). However, in the case of benzaldehyde and phenylacetaldehyde, analysis was done according to the HPLC method described below for the veratryl alcohol/methylglyoxal interconversion. Formaldehyde solutions were prepared by heating paraformaldehyde in water for $8 \mathrm{~h}$ at $100^{\circ} \mathrm{C}$.

Substrate specificity. Values for $V_{\max }^{\prime}, K_{\mathrm{m}}^{\prime}$ and $K^{\prime}{ }_{\mathrm{i}}$ of the NDMA-linked dehydrogenase activity of np-ADH were determined by varying the concentration of the alcohol or aldehyde substrate (in the range from $1 \mu \mathrm{M}$ to $200 \mathrm{mM}$, or up to saturation) in the assay mixture at a constant concentration of NDMA $(28 \mu \mathrm{M})$. The apparent kinetic parameter values of the alcohol: carbonyl oxidoreductase activity of np-ADH were determined by varying the concentration of the aldehyde or ketone substrate (from $1 \mu \mathrm{M}$ up to saturation) at a fixed concentration of veratryl alcohol $(1 \mathrm{mM})$ and measuring the initial rates of veratraldehyde formation at $310 \mathrm{~nm}\left(\varepsilon_{310}=\right.$ $9300 \mathrm{M}^{-1} \mathrm{~cm}^{-1}$ ). The steady-state kinetic data were analysed by non-linear regression using an equation derived from Michaelis-Menten kinetics (with a single substrate), including a substrate-inhibition term (Cornish-Bowden, 1995), using Igor Pro software (WaveMetrics) on a Power Macintosh G3 computer (Apple).

Interconversion of the veratryl alcohol/methylglyoxal combination. The np-ADH-catalysed oxidation of veratryl alcohol to veratraldehyde with the concomitant reduction of methylglyoxal was carried out at $20^{\circ} \mathrm{C}$ in a quartz cuvette. The reaction mixture (total volume $2 \mathrm{ml}$ ) consisted of $10 \mathrm{mM}$ potassium phosphate buffer, $\mathrm{pH} 7 \cdot 0,0.15 \mathrm{mM}$ veratryl alcohol, $1.0 \mathrm{mM}$ methylglyoxal and $0.1 \mu \mathrm{M} \mathrm{np}-\mathrm{ADH}$. The progression of the conversion with time was monitored by measuring veratraldehyde formation at $310 \mathrm{~nm}$. Samples $(25 \mu \mathrm{l})$ were taken at regular intervals and the reaction was quenched by adding $50 \mu \mathrm{l}$ of the HPLC column eluent (aqueous $30 \%, \mathrm{v} / \mathrm{v}$, acetonitrile containing $1 \%, \mathrm{v} / \mathrm{v}$, acetic acid), and centrifuging $(2 \mathrm{~min}$ at $20000 \mathrm{~g}$ ). An aliquot of the supernatant $(20 \mu \mathrm{l})$ was applied to a Nova-pak $\mathrm{C}_{18}$ reversed-phase column $(150 \times 3.9 \mathrm{~mm}$, Waters) followed by isocratic elution at a flow rate of $0.8 \mathrm{ml} \mathrm{min}^{-1}$ (Piersma, 1998). The eluate was monitored at $236 \mathrm{~nm}, 278 \mathrm{~nm}$ and $310 \mathrm{~nm}$ using a UV/VIS photodiodearray detector (Hewlett Packard, model 1040 A). Baseline separation could be achieved with this setup for veratryl alcohol, veratraldehyde and veratric acid, allowing reliable 
integration of the peak areas of the compounds using Chemstation chromatography software (Hewlett Packard). Quantitative data were obtained by using calibration curves of the authentic compounds chromatographed in the same way.

Molecular mass determinations. The subunit molecular mass of np-ADH was determined by SDS-PAGE (Laemmli, 1970) using $8-25 \%$ polyacrylamide gradient gels on a Phast-System (Pharmacia) according to the manufacturer's instructions. A low-molecular-mass marker kit (Pharmacia) was used for calibration and Coomassie brilliant blue R250 for protein staining. The molecular mass of native np-ADH was determined by gel filtration on a Superdex $200(30 \times 1 \mathrm{~cm})$ column equilibrated with $10 \mathrm{mM}$ potassium phosphate buffer,

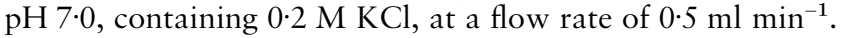
Blue dextran $(2000 \mathrm{kDa})$, thyroglobulin $(669 \mathrm{kDa})$, ferritin $(440 \mathrm{kDa})$, catalase $(232 \mathrm{kDa})$, aldolase $(158 \mathrm{kDa})$ and bovine serum albumin (BSA, $67 \mathrm{kDa}$ ) were used as molecular mass references.

Protein determination. Protein concentrations were estimated using the bicinchoninic acid/ $\mathrm{CuSO}_{4}$ method (Pierce) with desalted BSA as a standard (Smith et al., 1985).

$\mathrm{N}$-terminal sequence analysis. The $\mathrm{N}$-terminal amino acid sequence of the enzyme (the blotted band obtained with SDSPAGE) was determined by automated Edman degradation using a Procise 494 sequenator (Applied Biosystems Division, Perkin Elmer) running in pulsed-liquid mode.

Determination of bound NADH. The enzyme-bound chromophore was dissociated from the enzyme using a slightly modified urea-extraction procedure (Bystrykh et al., 1993a). For that purpose, an aliquot of enzyme in $0 \cdot 1 \mathrm{M}$ Tris $/ \mathrm{HCl}, \mathrm{pH}$ 8.5 , was brought to $6 \mathrm{M}$ urea by adding a saturated urea solution in the same buffer. The mixture was heated for $2 \mathrm{~min}$ at $85^{\circ} \mathrm{C}$. After cooling and centrifugation $(5 \mathrm{~min}$ at $20000 \mathrm{~g}$ ), the supernatant was applied to a MonoQ $(0.5 \times 5 \mathrm{~cm})$ column equilibrated with $10 \mathrm{mM}$ Tris $/ \mathrm{HCl}, \mathrm{pH}$ $8 \cdot 5$, containing $6 \mathrm{M}$ urea. Elution was done at a flow rate of $1 \mathrm{ml} \mathrm{min}{ }^{-1}$ with a linear gradient of $0-1 \mathrm{M} \mathrm{KCl}$ in the same buffer. The eluate was monitored with the UV/VIS photodiode-array detector. The resulting elution profile and the absorption spectra of the compounds corresponding to the peaks in the chromatogram were compared with those of urea-treated authentic NAD, NADH, NADP and NADPH.

Fluorescence spectroscopy. Fluorescence spectra were obtained at room temperature using a Shimadzu spectrofluorimeter, model RF-5001PC. Fluorescence emission spectra were recorded from 350 to $600 \mathrm{~nm}$ using a fixed excitation wavelength of $334 \mathrm{~nm}$ (bandwidth $3 \mathrm{~nm}$ ). Fluorescence excitation spectra were obtained by scanning from 250 to $400 \mathrm{~nm}$ and recording the fluorescence emission at a fixed wavelength of $430 \mathrm{~nm}$ (bandwidth $3 \mathrm{~nm}$ ).

\section{RESULTS}

\section{Induction studies}

R. erythropolis DSM 1069 utilized a large number of aliphatic and aromatic primary alcohols as sole carbon and energy source. During growth on these compounds, both NAD- and NDMA-dependent alcohol dehydrogenase activities were induced (Table 1), the latter suggesting the presence of one or more nicotinoprotein alcohol dehydrogenases. Attempts to detect the presence of an alcohol oxidase or an NADP-dependent alcohol dehydrogenase gave negative results (except for significant NADP-dependent coniferyl alcohol dehydrogenase activity after growth on this alcohol; see below). In extracts of cells grown on acetate + methanol, ethanol, propan-1-ol, veratryl alcohol or cyclohexanol, NDMAdependent methanol dehydrogenase activity was observed. Purification and characterization revealed that this activity derives from $\mathrm{MNO}$ (to be published elsewhere), in agreement with earlier indications of the presence of MNO in rhodococci (van Ophem et al., 1993; Nagy et al., 1995). Growth on each of the other alcohols, in particular on benzyl alcohol, 3phenylpropan-1-ol and butan-1-ol, induced significant NDMA-dependent benzyl alcohol dehydrogenase activity, whereas NDMA-dependent methanol dehydrogenase activity was absent, suggesting the presence of an NDMA-dependent alcohol dehydrogenase other than MNO. When benzyl alcohol in the assay was replaced by the alcohol on which the corresponding cells had grown, significant NDMA-dependent alcohol dehydrogenase activities were detected, showing apparent maximal velocities at low substrate concentrations (micromolar range, as indicated by the values given in parentheses in Table 1). In general, the NAD-dependent alcohol dehydrogenase activities in the extracts were very low, and maximal activities were obtained only at relatively high substrate concentrations (millimolar range), except in extracts of coniferyl-alcohol-grown cells. It is very likely that the coniferyl alcohol dehydrogenase activity derives from the NAD $(\mathrm{P})$-dependent coniferyl alcohol dehydrogenase already described for this organism (Jaeger et al., 1981; Jaeger, 1988).

\section{Purification and structural properties}

The induction studies indicated that benzyl alcohol as growth substrate gives rise to the highest level of NDMA-dependent alcohol dehydrogenase activity without inducing $\mathrm{MNO}$ or $\mathrm{NAD}(\mathrm{P})$-dependent alcohol dehydrogenase activities. Therefore, this alcohol was chosen as a growth substrate to produce cells as starting material for the purification of np-ADH. The data for the purification protocol of a typical batch are presented in Table 2. SDS-PAGE of the final preparation revealed a single band corresponding to an $M_{r}$ of 38000 ( $\pm 5 \%$ ). Gel-filtration chromatography of native enzyme yielded a single peak, which corresponded to an $M_{\mathrm{r}}$ of 150000 $( \pm 10 \%)$. Since overlaying of the chromatograms taken at 205,280 and $330 \mathrm{~nm}$ showed a single, symmetrical peak with the same retention time, it is concluded that the final enzyme preparation was homogeneous. A single N-terminal amino acid sequence was detected (Fig. 1), showing high sequence identity to that of np-ADH from A. methanolica (van Ophem et al., 1993), i.e. $77 \%$ identical amino acid residues out of 22. This suggested that the enzyme purified is an np-ADH which has, according to the data given above, a homotetrameric structure.

The absorption spectrum of the final preparation (Fig. $2 a$, solid line) showed that the enzyme contains a 
Table 1. Alcohol dehydrogenase activities exhibited by extracts of $R$. erythropolis DSM 1069

Cell-free extracts were assayed for NDMA-linked np-ADH and MNO activities (with $20 \mu \mathrm{M}$ benzyl alcohol, at $\mathrm{pH} 7 \cdot 0$, and with $25 \mathrm{mM}$ methanol, at $\mathrm{pH} 6 \cdot 3$, respectively), and for NDMA- and NADlinked 'growth-substrate' ('GS') dehydrogenase activities (at $\mathrm{pH} 7 \cdot 0$ and 9.0, respectively).

\begin{tabular}{|c|c|c|c|c|}
\hline \multirow[t]{3}{*}{ Growth substrate* } & \multicolumn{4}{|c|}{ Specific alcohol dehydrogenase activity $\dagger$} \\
\hline & \multicolumn{3}{|c|}{ NDMA-linked } & \multirow{2}{*}{$\begin{array}{c}\text { NAD-linked } \\
\text { 'GS' } \ddagger\end{array}$} \\
\hline & $\begin{array}{l}\text { Benzyl } \\
\text { alcohol }\end{array}$ & 'GS’‡ & Methanol & \\
\hline Methanol $(0.5 \%, \mathrm{v} / \mathrm{v})$ & $<1$ & $3 \cdot 5(25)$ & $3 \cdot 5$ & 0 \\
\hline Ethanol $(1 \%, v / v)$ & 1 & $1(0 \cdot 8)$ & $1 \cdot 1$ & $<1(21)$ \\
\hline Propan-1-ol $(0 \cdot 2 \%, \mathrm{v} / \mathrm{v})$ & 3 & ND & $<1$ & $2(13)$ \\
\hline Butan-1-ol $(0 \cdot 2 \%, \mathrm{v} / \mathrm{v})$ & 35 & $25(0 \cdot 04)$ & 0 & $6(16)$ \\
\hline Hexan-1-ol $(0 \cdot 1 \%, v / v)$ & 9 & $9(0 \cdot 04)$ & 0 & $4(16)$ \\
\hline Citronellol (1 mM) & 7 & $5(0 \cdot 009)$ & 0 & $<1(1)$ \\
\hline Benzyl alcohol (10 mM) & 54 & $54(0 \cdot 02)$ & 0 & 0 \\
\hline Veratryl alcohol (10 mM) & 8 & $7(0 \cdot 3)$ & $<1$ & $16(6)$ \\
\hline Vanillyl alcohol (5 mM) & 9 & $5(0 \cdot 9)$ & 0 & $4(2)$ \\
\hline Coniferyl alcohol (1 mM) & 4 & $3(0 \cdot 01)$ & 0 & $52(0 \cdot 4)$ \\
\hline 2-Phenylethanol (10 mM) & 4 & $5(0 \cdot 03)$ & 0 & $2(0 \cdot 7)$ \\
\hline 3-Phenylpropan-1-ol (10 mM) & 50 & $38(0 \cdot 06)$ & 0 & $11(5)$ \\
\hline Cyclohexanol $(10 \mathrm{mM})$ & 16 & $8(0 \cdot 4)$ & $<1$ & $<1(22)$ \\
\hline Sodium acetate $(0.5 \%, \mathrm{w} / \mathrm{v})$ & 0 & ND & 0 & ND \\
\hline D-Glucose $(0.5 \%, \mathrm{w} / \mathrm{v})$ & 0 & 0 & 0 & $<1(19)$ \\
\hline
\end{tabular}

ND, Not determined.

* Compounds used as sole carbon and energy source; final concentrations are given in parentheses.

† Expressed in nmol NDMA consumed or NADH formed $\operatorname{~min}^{-1}$ (mg protein $)^{-1}$.

$\ddagger$ Values in parentheses indicate an estimate of the concentration (in $\mathrm{mM}$ ) for optimal activity (see Methods).

$\$$ Methanol (not a growth substrate) was added as a cosubstrate $(0.5 \%, \mathrm{v} / \mathrm{v})$ to $0.5 \%(\mathrm{w} / \mathrm{v})$ sodium acetate.

Table 2. Summary of the purification of np-ADH from benzyl-alcohol-grown $R$. erythropolis

\begin{tabular}{|lrccc|}
\hline Purification step & $\begin{array}{c}\text { Total } \\
\text { protein } \\
(\mathbf{m g})\end{array}$ & $\begin{array}{c}\text { Specific } \\
\text { activity* } \\
(\mu \mathbf{m o l} \\
\left.\text { min }^{-1} \mathbf{~ m g}^{-1}\right)\end{array}$ & $\begin{array}{c}\text { Yield } \\
(\%)\end{array}$ & $\begin{array}{c}\text { Purification } \\
(- \text {-fold })\end{array}$ \\
\hline Cell-free extract & 1635 & $0 \cdot 3$ & 100 & 1 \\
Phenyl-Sepharose & 311 & $1 \cdot 3$ & 82 & 4 \\
Poros HQ & 58 & $3 \cdot 4$ & 40 & 11 \\
Superdex 200 & 30 & $4 \cdot 0$ & 24 & 13 \\
\hline
\end{tabular}

* Specific activities were determined with the np-ADH assay using benzyl alcohol $(20 \mu \mathrm{M}$, final concentration) as a substrate, and expressed in $\mu \mathrm{mol}$ NDMA reduced $\min ^{-1}$ (mg protein $)^{-1}$.

chromophore with an absorption maximum at $330 \mathrm{~nm}$. Fluorescence excitation and emission spectra (Fig. 2b, dashed and solid lines, respectively) of the enzyme displayed excitation maxima at $286 \mathrm{~nm}$ and $334 \mathrm{~nm}$, and an emission maximum at $431 \mathrm{~nm}$, characteristics in line with the presence of a pyridine nucleotide. Extraction and chromatography showed that the chromophore is indeed identical to NADH, the same cofactor which has been found in np-ADH from A. methanolica (van Ophem et al., 1993). Addition of acetaldehyde to the enzyme preparation bleached the absorbance of enzymebound NADH, which could be reversed by subsequent addition of ethanol (Fig. 2a, dashed and dotted lines, respectively). Thus, the nicotinoprotein alcohol dehydrogenase from $R$. erythropolis is an np-ADH, containing tightly, but not covalently bound NADH acting as cofactor.

\section{Catalytic performance and substrate specificity}

To get insight into the catalytic properties of np-ADH, its performance with respect to the forward and reverse reactions and its substrate specificities were determined. 


\begin{tabular}{|c|c|c|c|c|c|c|c|c|c|c|c|c|c|c|c|c|c|c|c|c|c|c|}
\hline & & & & & 5 & & & & & 10 & & & & & 15 & & & & & 20 & & \\
\hline R. erythropolis np-ADH & M & $\mathrm{K}$ & $\mathrm{T}$ & $\mathrm{K}$ & $\mathrm{A}$ & $\mathrm{A}$ & $\mathrm{V}$ & L & $F$ & $\mathrm{E}$ & $\mathrm{T}$ & $\mathrm{H}$ & $\mathrm{K}$ & $\mathrm{P}$ & $\mathrm{F}$ & $\mathrm{E}$ & I & $\mathrm{V}$ & $\mathrm{E}$ & L & $\mathrm{E}$ & $\mathrm{L}$ \\
\hline A. methanolica np-ADH & M & $\mathrm{K}$ & $\mathrm{T}$ & $\mathrm{K}$ & A & A & V & L & $\mathrm{H}$ & $\mathrm{S}$ & $\mathrm{A}$ & G & $\mathrm{K}$ & $\mathrm{P}$ & $\mathrm{F}$ & $\mathrm{E}$ & $I$ & $\mathrm{E}$ & $E$ & $\mathrm{~L}$ & $\mathrm{E}$ & $\mathrm{L}$ \\
\hline M. tuberculosis AdhD & $\mathrm{M}$ & $\mathrm{K}$ & $\mathrm{T}$ & $\mathrm{T}$ & $\mathrm{A}$ & $\mathrm{A}$ & $\mathrm{V}$ & $\mathrm{L}$ & $\mathrm{F}$ & $\mathrm{E}$ & A & G & $\mathrm{K}$ & $\mathrm{P}$ & $\mathrm{F}$ & $\mathrm{E}$ & $\mathrm{L}$ & M & $\mathrm{E}$ & $\mathrm{L}$ & $\mathrm{D}$ & $\mathrm{L}$ \\
\hline
\end{tabular}

Fig. 1. N-terminal amino acid sequence of $n p-A D H$ from $R$. erythropolis. The sequence is compared to that of $n p-A D H$ from A. methanolica (van Ophem et al., 1993), and to that of the AdhD gene product corresponding to the adhD gene from Mycobacterium tuberculosis H37Rv, which encodes a putative alcohol dehydrogenase according to Cole et al. (1998). Amino acid residues identical to those of $\mathrm{np}-\mathrm{ADH}$ from $R$. erythropolis are boxed.
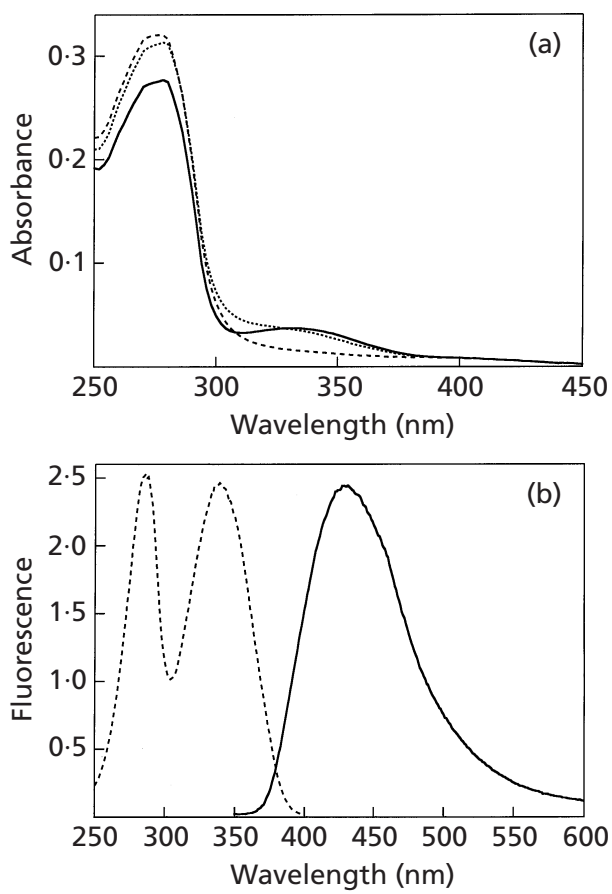

Fig. 2. (a) UV/visible absorption spectra of $n p-A D H$. The final preparation $\left(0.4 \mathrm{mg}\right.$ protein $\left.\mathrm{ml}^{-1}\right)$ in $10 \mathrm{mM}$ potassium phosphate buffer, $\mathrm{pH} 7 \cdot 0$, was measured as isolated (solid line), after the addition of acetaldehyde $(5 \mathrm{mM}$, dashed line), and subsequently ethanol ( $5 \mathrm{mM}$, dotted line). Spectra were corrected for volume changes. (b) Fluorescence spectra of $n p-$ $\mathrm{ADH}$. Excitation (dashed line) and emission (solid line) spectra were measured in $10 \mathrm{mM}$ potassium phosphate buffer, $\mathrm{pH} 7 \cdot 0$.

As shown in Table 3(a), using NDMA as electron acceptor np-ADH catalysed the oxidation of a large number of aliphatic, aromatic or branched primary alcohols (except methanol, ethanolamine, hydroxyacetone), secondary alcohols and polyols (except ethylene glycol, trans-cyclohexane-1,2-diol and cyclohexane-1,4-diol), but not aldehydes (except formaldehyde). On inspecting the specificity constants, it appears that primary alcohols are generally preferred over secondary alcohols and diols. In accordance with its nicotinoprotein character, steady-state experiments showed that the enzyme has a ping-pong kinetic mechanism, as judged from the parallel lines in a
Lineweaver-Burk plot for the couples ethanol/NDMA and veratryl alcohol/acetaldehyde (not shown). Using high concentrations of enzyme, very low but detectable aldehyde dismutase activities were measured for (turnover numbers in parentheses) formaldehyde $\left(0 \cdot 074 \mathrm{~s}^{-1}\right)$, acetaldehyde $\left(0.034 \mathrm{~s}^{-1}\right)$, propionaldehyde $\left(0.094 \mathrm{~s}^{-1}\right)$, methylglyoxal $\left(1.5 \mathrm{~s}^{-1}\right)$, benzaldehyde $\left(0.42 \mathrm{~s}^{-1}\right)$ and phenylacetaldehyde $\left(0 \cdot 60 \mathrm{~s}^{-1}\right)$.

np-ADH catalysed the reduction of various aldehydes (except formaldehyde) in the presence of an alcohol (Table $3 b$ ) such as ethanol, benzyl alcohol or veratryl alcohol (the latter was used in most cases because its oxidation to veratraldehyde can be measured conveniently at $310 \mathrm{~nm}$ ). When comparing both electron donor and acceptor substrate specificities (Table $3 a, b$ ), it appears that when np-ADH catalyses the oxidation of a certain alcohol, it also reduces the corresponding aldehyde or ketone. However, the specificity constants for carbonyl reduction are generally some orders of magnitude lower than those for the oxidation of the corresponding alcohol. np-ADH did not catalyse $\mathrm{NAD}(\mathrm{P}) \mathrm{H}$-dependent reduction of aldehydes or ketones.

From the apparent kinetic parameter values in Table $3(a, b)$, it follows that variation in the specificity constant values is mainly caused by the $K_{m}^{\prime}$ values, not by the $V_{\max }^{\prime}$ values. The best substrates are primary alcohols containing a phenyl group (compare methanol and ethanol with benzyl alcohol and 2-phenylethanol) or an aliphatic chain of a certain length (pentan-1-ol up to heptan-1-ol). Substitution of the phenyl ring (with hydroxyl and/or methoxy groups) results in less favourable substrates, unless the aliphatic chain is enlarged somewhat. Branching of the aliphatic chain also gives improvement (compare butan-1-ol with 3-methylbutan1-ol). Introduction of a double bond has a negative effect (compare propan-1-ol with 2-propen-1-ol) but this can be compensated by substitution with a phenyl group (compare 2-propen-1-ol with cinnamyl alcohol).

In many cases, severe substrate inhibition was observed (often in the submillimolar range), hampering the determination of kinetic parameter values, especially when there were small differences in $K_{\mathrm{m}}^{\prime}$ and $K^{\prime}{ }_{\mathrm{i}}$ values. This indicates that in such cases the substrate binds nearly equally well to the oxidized and the reduced enzyme forms. 
Table 3. Substrate specificity of np-ADH with (a) NDMA and (b) veratryl alcohol as electron acceptor and donor, respectively

\begin{tabular}{|c|c|c|c|c|}
\hline \multirow[t]{2}{*}{ Substrate } & \multicolumn{4}{|c|}{ Apparent kinetic constants } \\
\hline & $\begin{array}{c}V_{\max }^{\prime}(\mu \mathrm{mol} \\
\left.\min ^{-1} \mathrm{mg}^{-1}\right)\end{array}$ & $\boldsymbol{K}_{\mathrm{m}}^{\prime}{ }^{*}(\mathrm{mM})$ & $K_{\mathrm{i}}^{\prime}(\mathbf{m M})$ & $V_{\max }^{\prime} / K_{m}^{\prime}$ \\
\hline & \multicolumn{4}{|c|}{ (a) NDMA as electron acceptor } \\
\hline \multicolumn{5}{|l|}{ Primary alcohols } \\
\hline Ethanol & $2 \cdot 0$ & $0 \cdot 10$ & 105 & 19 \\
\hline Propan-1-ol & $2 \cdot 5$ & $0 \cdot 0037$ & $3 \cdot 8$ & 668 \\
\hline Butan-1-ol & $5 \cdot 8$ & $0 \cdot 010$ & $0 \cdot 068$ & 567 \\
\hline Pentan-1-ol & $2 \cdot 0$ & $<0.001$ & $0 \cdot 36$ & $>1950$ \\
\hline Hexan-1-ol & $2 \cdot 2$ & $<0 \cdot 001$ & $0 \cdot 24$ & $>2180$ \\
\hline Heptan-1-ol & $2 \cdot 7$ & $0 \cdot 0011$ & $0 \cdot 042$ & 2452 \\
\hline Octan-1-ol & $3 \cdot 5$ & $0 \cdot 059$ & $0 \cdot 13$ & 59 \\
\hline 2-Propen-1-ol & $3 \cdot 0$ & $0 \cdot 028$ & $8 \cdot 1$ & 108 \\
\hline Isobutanol & $3 \cdot 3$ & $0 \cdot 0072$ & $1 \cdot 9$ & 453 \\
\hline 3-Methylbutan-1-ol & $3 \cdot 1$ & $0 \cdot 0028$ & $0 \cdot 053$ & 1136 \\
\hline Citronellol & $1 \cdot 9$ & $<0 \cdot 001$ & $0 \cdot 11$ & $>1925$ \\
\hline Benzyl alcohol & $4 \cdot 9$ & $0 \cdot 0018$ & $0 \cdot 081$ & 2734 \\
\hline 4-Hydroxybenzyl alcohol & 0.79 & $0 \cdot 0047$ & $6 \cdot 1$ & 168 \\
\hline Vanillyl alcohol & $2 \cdot 0$ & $0 \cdot 39$ & $6 \cdot 0$ & $5 \cdot 2$ \\
\hline Veratryl alcohol & $1 \cdot 8$ & $0 \cdot 16$ & $5 \cdot 9$ & 12 \\
\hline 2-Phenylethanol & $2 \cdot 6$ & $0 \cdot 0070$ & $2 \cdot 2$ & 391 \\
\hline 2-Phenylpropan-1-ol & $1 \cdot 8$ & $0 \cdot 056$ & $2 \cdot 6$ & 33 \\
\hline 3-Phenylpropan-1-ol & $2 \cdot 4$ & $0 \cdot 014$ & $0 \cdot 58$ & 170 \\
\hline 3-(4-Hydroxyphenyl)propan-1-ol & $2 \cdot 7$ & $0 \cdot 0019$ & $0 \cdot 92$ & 420 \\
\hline Cinnamyl alcohol & $3 \cdot 4$ & $0 \cdot 0036$ & $0 \cdot 18$ & 947 \\
\hline Coniferyl alcohol & $0 \cdot 92$ & $0 \cdot 0055$ & $4 \cdot 3$ & 168 \\
\hline 2-Phenylbutan-1-ol & $1 \cdot 3$ & $0 \cdot 20$ & $1 \cdot 9$ & $6 \cdot 5$ \\
\hline 4-(4-Methoxyphenyl) butan-1-ol & $4 \cdot 0$ & $0 \cdot 0059$ & $0 \cdot 039$ & 670 \\
\hline \multicolumn{5}{|l|}{ Secondary alcohols } \\
\hline Propan-2-ol & $0 \cdot 16$ & $6 \cdot 0$ & $\infty$ & $0 \cdot 027$ \\
\hline Butan-2-ol & $0 \cdot 81$ & $4 \cdot 1$ & 13 & $0 \cdot 20$ \\
\hline Pentan-2-ol & $2 \cdot 0$ & $1 \cdot 3$ & $4 \cdot 7$ & $1 \cdot 5$ \\
\hline Hexan-2-ol & $2 \cdot 6$ & $0 \cdot 83$ & $2 \cdot 3$ & $3 \cdot 1$ \\
\hline Heptan-2-ol & $1 \cdot 1$ & $0 \cdot 070$ & $4 \cdot 9$ & 15 \\
\hline Octan-2-ol & $0 \cdot 75$ & $0 \cdot 12$ & $\infty$ & $6 \cdot 2$ \\
\hline 3-Methylheptan-4-ol & $6 \cdot 6$ & $9 \cdot 1$ & $\infty$ & $0 \cdot 73$ \\
\hline 4-Methylheptan-3-ol & $0 \cdot 58$ & $0 \cdot 28$ & $\infty$ & $2 \cdot 1$ \\
\hline 1-Phenylethanol & $1 \cdot 2$ & $2 \cdot 8$ & 14 & $0 \cdot 44$ \\
\hline 1-Phenylpropan-1-ol & $0 \cdot 84$ & $0 \cdot 55$ & 22 & $1 \cdot 5$ \\
\hline 1-Phenylpropan-2-ol & $1 \cdot 9$ & $1 \cdot 6$ & $4 \cdot 6$ & $1 \cdot 2$ \\
\hline 1-Phenylbutan-2-ol & $1 \cdot 5$ & $0 \cdot 55$ & $1 \cdot 4$ & $2 \cdot 7$ \\
\hline Cyclohexanol & $1 \cdot 9$ & $0 \cdot 19$ & $1 \cdot 6$ & $9 \cdot 9$ \\
\hline \multicolumn{5}{|l|}{ Diols } \\
\hline Propane-1,2-diol & $2 \cdot 3$ & 35 & $\infty$ & 0.065 \\
\hline Propane-1,3-diol & $3 \cdot 0$ & $4 \cdot 1$ & 194 & $0 \cdot 72$ \\
\hline 3-Butene-1,2-diol & $1 \cdot 6$ & $8 \cdot 3$ & 388 & $0 \cdot 19$ \\
\hline Pentane-1,2-diol & $2 \cdot 0$ & $0 \cdot 20$ & 47 & $9 \cdot 9$ \\
\hline 1-Phenylethane-1,2-diol & $1 \cdot 4$ & $3 \cdot 1$ & 99 & $0 \cdot 46$ \\
\hline \multicolumn{5}{|l|}{ Aldehydes } \\
\hline Formaldehyde & $3 \cdot 4$ & $0 \cdot 93$ & $5 \cdot 4$ & $3 \cdot 6$ \\
\hline
\end{tabular}


Table 3 (cont.)

\begin{tabular}{|c|c|c|c|c|}
\hline \multirow[t]{2}{*}{ Substrate } & \multicolumn{4}{|c|}{ Apparent kinetic constants } \\
\hline & $\begin{array}{c}V_{\max }^{\prime}(\mu \mathrm{mol} \\
\left.\min ^{-1} \mathrm{mg}^{-1}\right)\end{array}$ & $K_{\mathrm{m}}^{\prime} *(\mathrm{mM})$ & $K_{\mathrm{i}}^{\prime}(\mathbf{m M})$ & $V_{\max }^{\prime} / K_{\mathrm{m}}^{\prime}$ \\
\hline & \multicolumn{4}{|c|}{ (b) Veratryl alcohol as electron donor } \\
\hline \multicolumn{5}{|l|}{ Aldehydes } \\
\hline Acetaldehyde & $2 \cdot 1$ & $4 \cdot 95$ & $\infty$ & $0 \cdot 42$ \\
\hline Benzaldehyde & $3 \cdot 7$ & $0 \cdot 083$ & $0 \cdot 035$ & 45 \\
\hline 2-Phenylpropionaldehyde & $2 \cdot 38$ & $0 \cdot 088$ & $\infty$ & 27 \\
\hline 3-Phenylpropionaldehyde & $8 \cdot 32$ & $0 \cdot 14$ & $0 \cdot 41$ & 59 \\
\hline 3-Phenylbutyraldehyde & $8 \cdot 52$ & $0 \cdot 12$ & $0 \cdot 31$ & 73 \\
\hline Glyoxal & $1 \cdot 0$ & 242 & $\infty$ & $0 \cdot 004$ \\
\hline Methylglyoxal & $4 \cdot 5$ & $3 \cdot 2$ & $5 \cdot 2$ & $1 \cdot 4$ \\
\hline Phenylglyoxal & $5 \cdot 1$ & $0 \cdot 21$ & $1 \cdot 3$ & 24 \\
\hline \multicolumn{5}{|l|}{ Ketones } \\
\hline Hydroxyacetone & $0 \cdot 15$ & 38 & $\infty$ & $0 \cdot 004$ \\
\hline Cyclohexanone & $0 \cdot 097$ & $1 \cdot 6$ & $\infty$ & $0 \cdot 06$ \\
\hline \multicolumn{5}{|l|}{ Nitrosoanilines } \\
\hline NDMA† & $1 \cdot 7$ & $0 \cdot 0041$ & $\infty$ & 425 \\
\hline
\end{tabular}

$\infty$ Substrate inhibition could not be observed within the concentration range tested.

* The lower limit of the determination of $K_{m}$ with NDMA as electron acceptor was 0.001 mM.

†Veratryl alcohol ( $1 \mathrm{mM}$, final concentration) in the assay (see Methods) was replaced by ethanol $(0.5 \mathrm{mM}$, final concentration) and initial rates of the reduction of NDMA were measured at $440 \mathrm{~nm}$.

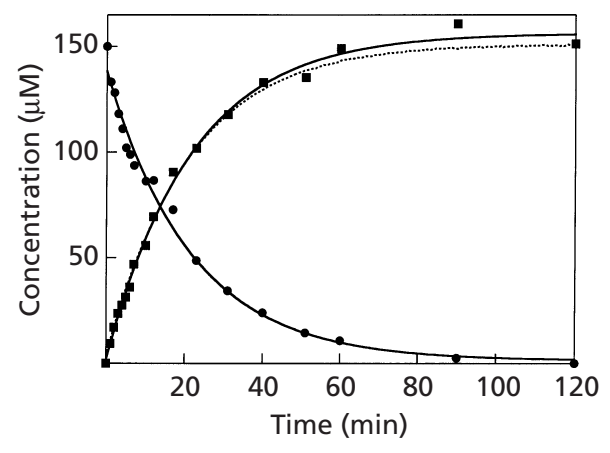

Fig. 3. Interconversion of veratryl alcohol and methylglyoxal by np-ADH. The progression of the conversion was monitored (dotted line) by following the rise in absorbance at $310 \mathrm{~nm}$ (due to formation of veratraldehyde) as well as by HPLC, measuring the veratryl alcohol (๑) and veratraldehyde concentrations ( $\square$ ). Fitting (solid lines) of the data was carried out using a single exponential equation.

\section{Conversion experiments}

For reasons of analytical simplicity, most enzymecatalysed conversion experiments were carried out with the couple veratryl alcohol/methylglyoxal. As shown in Fig. 3, a small amount of np-ADH catalysed the complete oxidation of veratryl alcohol into veratraldehyde with a stoichiometric amount of methyl- glyoxal as electron acceptor, in line with the fact that no veratric acid was found in the final reaction mixture. Complete conversion was also achieved using the couple veratraldehyde/ethanol, although the reaction proceeded approximately 10 -fold slower than that for the couple veratryl alcohol/methylglyoxal. These observations indicate that np-ADH is stable for several hours in mixtures of alcohols and aldehydes during catalysis. Rapid, irreversible inactivation of np-ADH was observed (typically within a few minutes) when performing alcohol oxidation in the presence of NDMA (not shown). This phenomenon could be partly suppressed by adding DTT (or other thiols) to the assay mixture. Incubating the enzyme with solely NDMA, an alcohol, or an aldehyde did not lead to any inactivation (unpublished results). It seems, therefore, that the inactivation of np-ADH in the assay mixture is caused by products generated by the reduction of NDMA, an observation which has also been made in the case of horse liver alcohol dehydrogenase (Dunn \& Bernard, 1971).

\section{DISCUSSION}

From the results described here, it is concluded that benzyl-alcohol-grown R. erythropolis DSM 1069 produces np-ADH as the sole alcohol dehydrogenase. In theory, it is possible that benzyl alcohol is oxidized by another alcohol dehydrogenase, requiring unusual assay conditions, and that $\mathrm{np}-\mathrm{ADH}$ has a role in dissimilation 
Table 4. Presence in various alcohol dehydrogenases of amino acid residues regarded as characteristic for np-ADH (from A. methanolica)

Amino acid residues identical to those in np-ADH from A. methanolica are shown in bold. Nonidentical, but analogous residues are in normal type. Non-identical and non-analogous residues are in italics. Abbreviations: np-ADH A. met., nicotinoprotein alcohol dehydrogenase from $A$. methanolica; AdhD and AdhB M. tub., gene products from M. tuberculosis H37Rv encoded by the $a d h D$ and $a d h B$ genes, respectively, which have been assigned as putative alcohol dehydrogenases by Cole et al. (1998); hyp-ADH R. rho., gene product from R. rhodochrous, whose corresponding gene is found in a plasmid-located operon related to haloalkane dehalogenation, which has been assigned as a hypothetical alcohol dehydrogenase by Kulakova et al. (1997). Data from Eklund et al. (1990) for the corresponding residues of NAD-dependent alcohol dehydrogenase from horse liver (the ethanol-active subunit: E-type) are included for comparison.

\begin{tabular}{|c|c|c|c|c|c|}
\hline Residue* & $\begin{array}{c}\text { np-ADH } \\
\text { A. met. }\end{array}$ & $\begin{array}{l}\text { AdhD } \\
M . t u b .\end{array}$ & $\begin{array}{l}\text { hyp-ADH } \\
\text { R. rho. }\end{array}$ & $\begin{array}{l}\text { AdhB } \\
\text { M. tub. }\end{array}$ & $\begin{array}{c}\text { ADH (E-type) } \\
\text { horse liver }\end{array}$ \\
\hline \multicolumn{6}{|l|}{ Inner } \\
\hline 48 & Ser & Ser & Ser & Ser & Ser \\
\hline 93 & Phe & Phe & Phe & Phe & Phe \\
\hline 140 & Met & Met & Met & Met & Phe \\
\hline 141 & Cys & Cys & Cys & $T h r$ & Leu \\
\hline \multicolumn{6}{|l|}{ Middle } \\
\hline 57 & Leu & Leu & Leu & Ile & Leu \\
\hline 116 & Ala & Ala & Gln & Ala & Leu \\
\hline 294 & Leu & Leu & Leu & Ile & Val \\
\hline 318 & Leu & Leu & Leu & Ile & Ile \\
\hline \multicolumn{6}{|l|}{ Outer } \\
\hline 110 & Leu & Leu & Leu & Leu & Phe \\
\hline 306 & Val & Asp & Asp & Met & Met \\
\hline 309 & Leu & Leu & Leu & Leu & Leu \\
\hline \multicolumn{6}{|l|}{ Catalytic Zn } \\
\hline 46 & Cys & Cys & Cys & Cys & Cys \\
\hline 67 & His & His & His & His & His \\
\hline 174 & Cys & Cys & Cys & Cys & Cys \\
\hline \multicolumn{6}{|l|}{ NAD $(H)$-binding } \\
\hline 47 & His & His & His & Arg & Arg \\
\hline 48 & Ser & Ser & Ser & Ser & Ser \\
\hline 51 & His & His & His & His & His \\
\hline 269 & Val & Val & $T h r$ & Val & Ile \\
\hline 271 & Val & Val & Gly & Leu & Arg \\
\hline 369 & Arg & Arg & Arg & Arg & Arg \\
\hline Sequence length (aa) & 371 & 368 & 370 & 375 & 375 \\
\hline Sequence identity (\%) & 100 & 78 & 51 & 46 & 35 \\
\hline Sequence similarity (\%) & 100 & 86 & 69 & 65 & 52 \\
\hline
\end{tabular}

*Inner, middle and outer refer to different spheres of the substrate binding-pocket of the class 1 NADdependent alcohol dehydrogenase from horse liver (Eklund et al., 1990; Piersma, 1998). Also included are the regions involved in the binding of the catalytic zinc ion and the pyridine nucleotide coenzyme.

of the product, benzaldehyde. However, since np-ADH shows no dehydrogenase activity and a very low dismutase activity for this compound, the latter possibility can be excluded. Since no other candidate functioning as electron acceptor for np-ADH is present during cultivation of the organism on benzyl alcohol, it seems logical that the organism's respiratory chain is the electron acceptor for np-ADH. Evidence has been provided for this in the case of MNO (Bystrykh et al., 1997).
In view of the induction of np-ADH by many alcohols, as deduced from the activity exhibited by extracts in the assay with benzyl alcohol and NDMA, the absence or low activity of other alcohol dehydrogenases, and the broad substrate specificity of np-ADH, the enzyme may be the general alcohol-oxidizing enzyme for R. erythropolis DSM 1069. Since its assay is not standard practice, the significance of np-ADH may be even wider, as it may have been overlooked so far in other organisms. Accordingly, a search in the databases was made to see 
whether structural evidence could be found. It appeared that the N-terminal amino acid sequence of the AdhD gene product of Mycobacterium tuberculosis H37Rv (Cole et al., 1998), which was designated by the authors as a putative alcohol dehydrogenase, has $73 \%$ identical amino acids, as shown in Fig. 1. Also, a significant sequence identity $(51 \%)$ was observed with a hypothetical alcohol dehydrogenase from $R$. rhodochrous NCIMB 13064, whose corresponding gene occurs in a dehalogenation operon (Kulakova et al., 1997), and with the AdhB gene product ( $46 \%$ ) from M. tuberculosis (not shown). Recently, the complete amino acid sequence of np-ADH from A. methanolica has been determined and structural modelling was carried out using this sequence and the known three-dimensional structure of horse liver alcohol dehydrogenase (see Piersma, 1998). Taking the differences with respect to structural and catalytic aspects into account, this provided a number of amino acid residues which can be used as markers to distinguish between the two types of alcohol dehydrogenase (Table 4). Applying this to the sequences found in the databases, it appears that characteristic amino acid residues for np$\mathrm{ADH}$ are present, most of them in the gene product of the $a d h D$ gene of M. tuberculosis and fewer in those of the hypothetical alcohol dehydrogenase from $R$. rhodochrous and the AdhB gene product of M. tuberculosis (Table 4). It can be anticipated, therefore, that np-ADHs may also be found in other nocardioform actinomycetes.

The ability of np-ADH to interconvert alcohols and aldehydes may be physiologically important under conditions where such a combination occurs, e.g. in the biodegradation of wood, where a complex interplay of aldehydes and alcohols is responsible for generating $\mathrm{H}_{2} \mathrm{O}_{2}$-activated peroxidase and reactive intermediates for attacking lignin (Kersten et al., 1990). Benefits of using a nicotinoprotein alcohol dehydrogenase instead of an $\mathrm{NAD}(\mathrm{P})$-dependent alcohol dehydrogenase for this could be that the interconversion is not directly affected by the redox balance of the cell (the activities of np$\mathrm{ADH}$ are not affected by the intracellular NAD/NADH ratio). This property as well as the ability of np-ADH to catalyse these reactions in the absence of (added) coenzyme and, as shown here, its stability in this, could well be exploited in industrially relevant conversions.

\section{ACKNOWLEDGEMENTS}

This work was financially supported by the Ministry of Economic Affairs, the Ministry of Education, Culture and Science, and the Ministry of Agriculture, Nature Management and Fishery, in the framework of an industrially relevant research programme of the Association of Biotechnology Centres in The Netherlands (ABON).

\section{REFERENCES}

Ashraf, W. \& Murrell, J. C. (1990). Purification and characterization of a $\mathrm{NAD}^{+}$-dependent secondary alcohol dehydrogenase from propane-grown Rhodococcus rhodochrous PNKb1. Arch Microbiol 153, 163-168.

Ashraf, W. \& Murrell, J. C. (1992). Genetic, biochemical and immunological evidence for the involvement of two alcohol dehydrogenases in the metabolism of propane by Rhodococcus rhodochrous PNKb1. Arch Microbiol 157, 488-492.

Bell, K. S., Philp, J. C., Aw, D. W. J. \& Christofi, N. (1998). The genus Rhodococcus. J Appl Microbiol 85, 195-210.

Bystrykh, L. V., Vonck, J., van Bruggen, E. F. J., van Beeumen, J., Samyn, B., Govorukhina, N. I., Arfman, N., Duine, J.A. \& Dijkhuizen, L. (1993a). Electron microscopic analysis and structural characterization of novel $\mathrm{NADP}(\mathrm{H})$-containing methanol: $N, N^{\prime}$-dimethyl-4-nitrosoaniline oxidoreductases from the Gram-positive methylotrophic bacteria Amycolatopsis methanolica and Mycobacterium gastri MB19. J Bacteriol 175, 1814-1822.

Bystrykh, L. V., Govorukhina, N. I., van Ophem, P. W., Hektor, H. J., Dijkhuizen, L. \& Duine, J. A. (1993b). Formaldehyde dismutase activities in Gram-positive bacteria oxidizing methanol. J Gen Microbiol 139, 1979-1985.

Bystrykh, L. V., Govorukhina, N. I., Dijkhuizen, L. \& Duine, J. A. (1997). Tetrazolium dye-linked alcohol dehydrogenase of the methylotrophic actinomycete Amycolatopsis methanolica is a three-component complex. Eur J Biochem 247, 280-287.

Cole, S. T., Brosch, R., Parkhill, J. \& 38 other authors (1998). Deciphering the biology of Mycobacterium tuberculosis from the complete genome sequence. Nature 393, 537-544.

Cornish-Bowden, A. (1995). Fundamentals of Enzyme Kinetics, 2nd edn. London: Portland Press.

Duine, J. A., Frank, J. \& Berkhout, M. P. J. (1984). NAD-dependent, PQQ-containing methanol dehydrogenase: a bacterial dehydrogenase in a multienzyme complex. FEBS Lett 168, 217-221.

Dunn, M. F. \& Bernard, S. A. (1971). Rapid kinetic evidence for adduct formation between the substrate $p$-nitroso- $N$, N-dimethylaniline and reduced nicotinamide-adenine dinucleotide during enzymic reduction. Biochemistry 10, 4569-4575.

Eggeling, L. \& Sahm, H. (1984). An unusual formaldehyde oxidizing system in Rhodococcus erythropolis grown on compounds containing methyl groups. FEMS Microbiol Lett 25, 253-257.

Eggeling, L. \& Sahm, H. (1985). The formaldehyde dehydrogenase of Rhodococcus erythropolis, a trimeric enzyme requiring a cofactor and active with alcohols. Eur J Biochem 150, 129-134.

Eklund, H., Müller-Wille, P. \& Horjales, E. (1990). Comparison of three classes of human liver alcohol dehydrogenase. Emphasis on different substrate binding pockets. Eur J Biochem 193, 303-310.

Finnerty, W. R. (1992). The biology and genetics of the genus Rhodococcus. Annu Rev Microbiol 46, 193-218.

Geerlof, A., van Tol, J. B. A., Jongejan, J. A. \& Duine, J. A. (1994). Enantioselective conversion of the racemic $\mathrm{C}_{3}$-alcohol synthons, glycidol (2,3-epoxy-1-propanol), and solketal (2,2-dimethyl-4(hydroxymethyl)-1,3-dioxolane) by quinohaemoprotein alcohol dehydrogenases and bacteria containing such enzymes. Biosci Biotechnol Biochem 58, 1028-1036.

Hektor, H. J. (1997). Physiology and biochemistry of primary alcohol oxidation in the Gram-positive bacteria Amycolatopsis methanolica and Bacillus methanolicus. PhD thesis, Groningen State University.

Hektor, H. J. \& Dijkhuizen, L. (1996). Mutational analysis of primary alcohol metabolism in the methylotrophic actinomycete Amycolatopsis methanolica. FEMS Microbiol Lett 144, 73-79.

Jaeger, E. (1988). Purification of coniferyl alcohol dehydrogenase from Rhodococcus erythropolis. Methods Enzymol 161, 301-306.

Jaeger, E., Eggeling, L. \& Sahm, H. (1981). Partial purification and characterization of a coniferyl alcohol dehydrogenase from Rhodococcus erythropolis. Curr Microbiol 6, 333-336. 
Kersten, P. J., Stephens, S. K. \& Kirk, T. K. (1990). Glyoxal oxidase and the extracellular peroxidases of Phanerochaete chrysosporium. In Biotechnology in Pulp and Paper Manufacture, pp. 457-463. Edited by T. K. Kirk \& H.-M. Chang. Stoneham, MA: Butterworth-Heinemann.

Krier, F., Kreit, J. \& Millière, J. B. (1998). Characterization of partially purified alcohol dehydrogenase from Rhodococcus sp. strain GK1. Lett Appl Microbiol 26, 283-287.

Kulakova, A. N., Larkin, M. J. \& Kulakov, L. A. (1997). The plasmid-located haloalkane dehalogenase gene from Rhodococcus rhodochrous NCIMB 13064. Microbiology 143, 109-115.

Laemmli, U. K. (1970). Cleavage of structural proteins during assembly of the head of bacteriophage T4. Nature 227, 680-685.

Ludwig, B., Akundi, A. \& Kendall, K. (1995). A long-chain secondary alcohol dehydrogenase from Rhodococcus erythropolis ATCC 4277. Appl Environ Microbiol 61, 3729-3733.

Misset-Smits, M., van Ophem, P. W., Sakuda, S. \& Duine, J. A. (1997). Mycothiol, 1-O- $\left(2^{\prime}-[N\right.$-acetyl-L-cysteinyl $]$ amino- $2^{\prime}-$ deoxy- $\alpha$-D-glucopyranosyl)-D-myo-inositol, is the factor of $\mathrm{NAD} /$ factor-dependent formaldehyde dehydrogenase. FEBS Lett 409, 221-222.

Nagy, I., Verheijen, S., de Schrijver, A., van Damme, J., Proost, P., Schoofs, G., Vanderleyden, J. \& de Mot, R. (1995). Characterization of the Rhodococcus sp. NI86/21 gene encoding alcohol: $N, N^{\prime}$-dimethyl-4-nitrosoaniline oxidoreductase inducible by atrazine and thiocarbamate herbicides. Arch Microbiol 163, 439-446.

van Ophem, P. W. \& Duine, J. A. (1994). NAD- and co-substrate (GSH or factor)-dependent formaldehyde dehydrogenases from methylotrophic microorganisms act as a class III alcohol dehydrogenase. FEMS Microbiol Lett 116, 87-94.

van Ophem, P. W., van Beeumen, J. \& Duine, J. A. (1992). NADlinked, factor-dependent formaldehyde dehydrogenase or trimeric, zinc-containing, long-chain alcohol dehydrogenase from Amycolatopsis methanolica. Eur J Biochem 206, 511-518. van Ophem, P. W., van Beeumen, J. \& Duine, J. A. (1993). Nicotinoprotein (NAD(P)-containing) alcohol/aldehyde oxidoreductases. Purification and characterization of a novel type from Amycolatopsis methanolica. Eur J Biochem 212, 819-826.

Peters, J., Zelinski, T. \& Kula, M.-R. (1992). Studies on the distribution and regulation of microbial keto ester reductases. Appl Microbiol Biotechnol 38, 334-340.

Peters, J., Zelinski, T., Minuth, T. \& Kula, M.-R. (1993). Synthetic applications of the carbonyl-reductases isolated from Candida parapsilosis and Rhodococcus erythropolis. Tetrahedron Asymm 4, 1683-1692.

Piersma, S. R. (1998). Structure and catalytic mechanism of nicotinoprotein alcohol dehydrogenases from Amycolatopsis methanolica. PhD Thesis, Delft University of Technology.

Piersma, S. R., Visser, A. J. W. G., de Vries, S. \& Duine, J. A. (1998). Optical spectroscopy of nicotinoprotein alcohol dehydrogenase from Amycolatopsis methanolica: a comparison with horse liver alcohol dehydrogenase and UDP-galactose epimerase. Biochemistry 37, 3068-3077.

de Schrijver, A., Nagy, I., Schoofs, G., Proost, P., Vanderleyden, J., van Pée, K.-H. \& de Mot, R. (1997). Thiocarbamate herbicideinducible nonheme haloperoxidase of Rhodococcus erythropolis NI86/21. Appl Environ Microbiol 63, 1911-1916.

Smith, P. K., Krohn, R. I., Hermanson, G. T. \& 7 other authors (1985). Measurement of protein using bicinchoninic acid. Anal Biochem 150, 76-85.

Warhurst, A. M. \& Fewson, C. A. (1994). Biotransformations catalyzed by the genus Rhodococcus. Crit Rev Biotechnol 14, 29-73.

Zelinski, T., Peters, J. \& Kula, M.-R. (1994). Purification and characterization of a novel carbonyl reductase isolated from Rhodococcus erythropolis. J Biotechnol 33, 283-292.

Received 16 August 1999; revised 2 November 1999; accepted 23 December 1999 